\title{
AN AERIAL RADIOLOGICAL SURVEY OF THE PORTSMOUTH GASEOUS DIFFUSION PLANT AND SURROUNDING AREA
}

PIKETON, OHIO 


\section{DISCLAIMER}

This report was prepared as an account of work sponsored by an agency of the United States Government. Neither the United States Government nor any agency thereof, nor any of their employees, makes any warranty, express or implied, or assumes any legal liability or responsibility for the accuracy, completeness, or usefulness of any information, apparatus, product, or process disclosed, or represents that its use would not infringe privately owned rights. Reference herein to any specific commercial product, process, or service by trade name, trademark, manufacturer, or otherwise, does not necessarily constitute or imply its endorsement, recommendation, or favoring by the United States Government or any agency thereof. The views and opinions of authors expressed herein do not necessarily state or reflect those of the United States Government or any agency thereof.

This report has been reproduced directly from the best available copy.

Available to DOE and DOE contractors from the Office of Scientific and Technical Information, P.O. Box 62, Oak Ridge, Tennessee 37831; prices available from (615) 576-8401.

Available to the public from the National Technical Information Service, U.S. Department of Commerce, 5285 Port Royal, Springfield, Virginia 22161. 


\section{DISCLAIMER}

Portions of this document may be illegible in electronic image products. Images are produced from the best available original document. 


\title{
AN AERIAL RADIOLOGICAL SURVEY OF THE PORTSMOUTH GASEOUS DIFFUSION PLANT AND SURROUNDING AREA
}

\author{
PIKETON, OHIO
}

DATE OF SURVEY: AUGUST 1993

Gabriel Sampoll-Ramirez

Project Scientist

\section{REVIEWED BY}

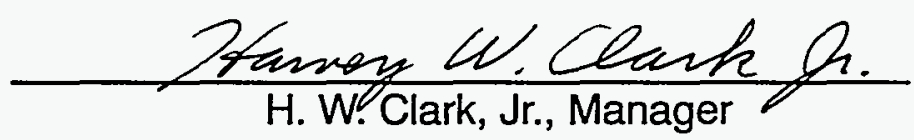

Radiation Science Section

This Document is UNCLASSIFIED

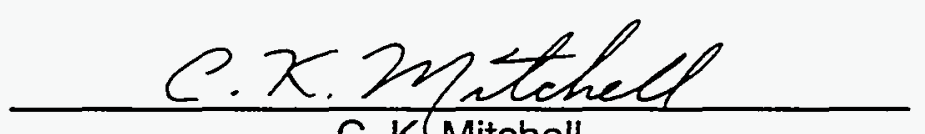

C. K. Mitchell

Classification Officer

This work was performed by EG\&G/EM for the United States Department of Energy under Contract Number DE-AC08-93NV11265. 


\begin{abstract}
An aerial radiological survey was conducted from August 10-16, 1993, over a 78-square-kilometer (30-square-mile) area of the Portsmouth Gaseous Diffusion Plant and surrounding area located near Portsmouth, Ohio. The survey was performed at a nominal altitude of 46 meters (150 feet) with a line spacing of 76 meters (250 feet). A contour map of the terrestrial gamma exposure rate extrapolated to 1 meter above ground level was prepared and overlaid on a set of United States Geological Survey topographic maps of the area and an aerial photograph of the plant. The terrestrial gamma exposure rates varied from about 7 to 14 microroentgens per hour at 1 meter above the ground. Protactinium-234m was observed at six sites within the boundaries of the plant. At a seventh site, only uranium-235 was observed. No other man-made, gamma ray-emitting radioactive material was present in a detectable quantity, either on or off the plant property.
\end{abstract}

Soil sample and pressurized ion chamber measurements were obtained at four locations within the survey boundaries to support the aerial data. The results of the aerial and ground-based measurements were found to agree within $\pm 7.5 \%$. 


\section{CONTENTS}

Abstract

\section{Sections}

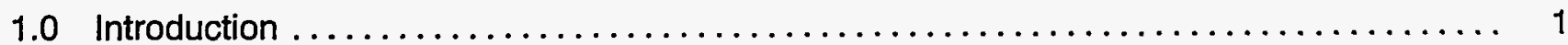

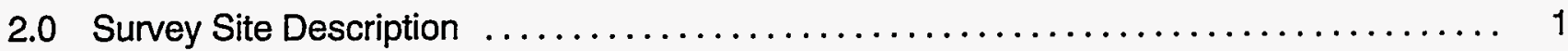

3.0 Natural Background Radiation $\ldots \ldots \ldots \ldots \ldots \ldots \ldots \ldots \ldots \ldots \ldots \ldots \ldots \ldots \ldots \ldots \ldots$

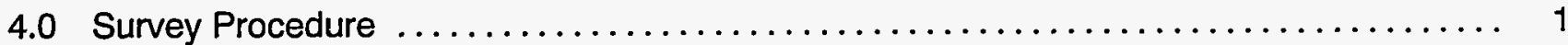

5.0 Survey Equipment $\ldots \ldots \ldots \ldots \ldots \ldots \ldots \ldots \ldots \ldots \ldots \ldots \ldots \ldots \ldots \ldots \ldots \ldots \ldots \ldots \ldots \ldots \ldots \ldots \ldots, 2$

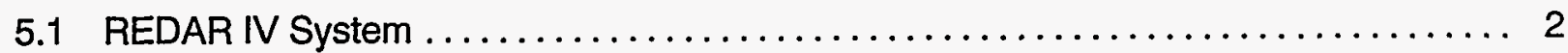

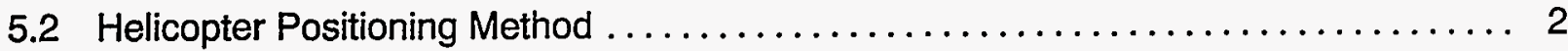

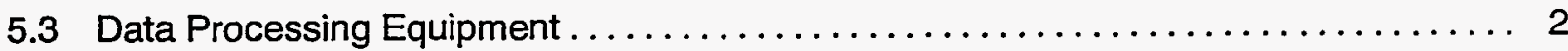

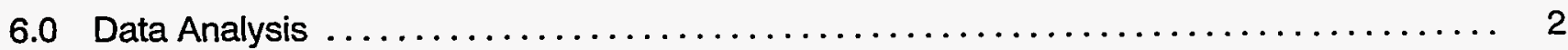

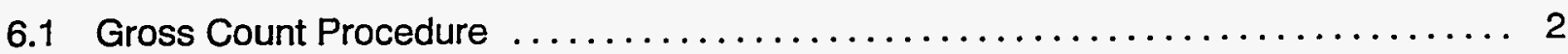

6.2 Man-Made Gross Count Extraction Procedure ........................ 3

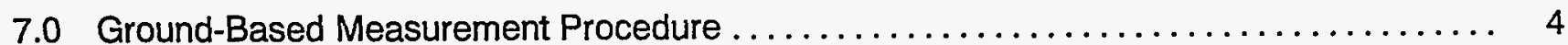

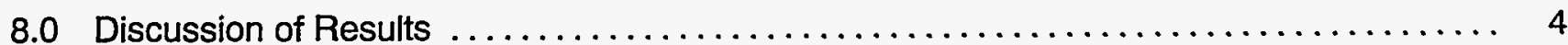

8.1 Terrestrial Gamma Exposure Rate Contour Map ...................... 4

8.2 Man-Made Gross Count Contour Analysis $\ldots \ldots \ldots \ldots \ldots \ldots \ldots \ldots \ldots \ldots \ldots \ldots \ldots \ldots$

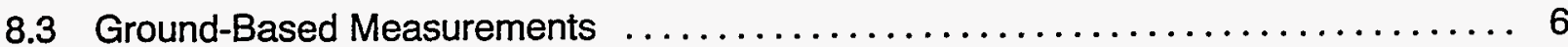

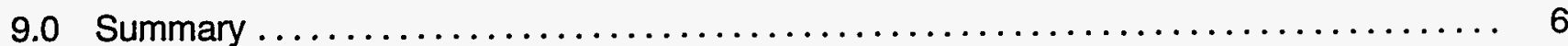

\section{Figures}

1 MBB BO-105 Helicopter with Detector Pods $\ldots \ldots \ldots \ldots \ldots \ldots \ldots \ldots \ldots \ldots \ldots \ldots, 2$

2 Background Gamma Energy Spectrum $\ldots \ldots \ldots \ldots \ldots \ldots \ldots \ldots \ldots \ldots \ldots \ldots \ldots \ldots \ldots$

3 Terrestrial Gamma Radiation Exposure Rate Contour Map $\ldots \ldots \ldots \ldots \ldots \ldots \ldots \ldots$............. 5

4 Man-Made Gamma Radiation Contour Map $\ldots \ldots \ldots \ldots \ldots \ldots \ldots \ldots \ldots \ldots \ldots \ldots$

5 Gamma Energy Spectra of the Seven Site Locations $\ldots \ldots \ldots \ldots \ldots \ldots \ldots \ldots \ldots . \quad 8$ 


\section{Tables}

1 Results of Soil Sample Analysis $\ldots \ldots \ldots \ldots \ldots \ldots \ldots \ldots \ldots \ldots \ldots \ldots \ldots \ldots \ldots \ldots \ldots \ldots \ldots \ldots, \quad 9$

2 Comparison of Aerial and Ground-Based Measurements .................. 10

3 Location of Man-Made Detected Sites ................................. 10

\section{Appendix}

A Survey Parameters

References

12 


\subsection{INTRODUCTION}

An aerial gamma ray survey was conducted from August 10-16, 1993, over the Portsmouth Gaseous Diffusion Plant (PORTS) and surrounding area. The PORTS is owned by the United States Department of Energy (DOE) and leased to the United States Enrichment Corporation (USEC). Martin Marietta Utility Services, Inc., operates the enrichment facilities for the USEC. The primary purpose of the PORTS is to provide enriched uranium fuel to the nuclear power industry. The aerial survey of the PORTS was conducted at the request of Martin Marietta Energy Systems, Inc., and sponsored by DOE in support of Environmental Restoration and Waste Management activities at the plant.

DOE maintains the Remote Sensing Laboratory (RSL) in Las Vegas, Nevada, and in Washington, D.C. The RSL is operated for DOE by EG\&G Energy Measurements (EG\&G/EM). One of the missions of the RSL is to manage the Aerial Measuring System (AMS), an aerial radiation surveillance program.

Since its inception in 1958, the AMS has continued a nationwide effort to document baseline radiological conditions surrounding nuclear energy-related sites. These sites include nuclear power plants, nuclear fuel manufacturing and processing plants, research laboratories, and private corporations employing nuclear materials. Under the direction of the DOE and at the request of federal or state agencies, the AMS has been deployed for various aerial radiological survey operations.

\subsection{SURVEY SITE DESCRIPTION}

The PORTS is located on a large, government-owned reservation near Piketon, Ohio, about 32 kilometers (20 miles) north of Portsmouth, Ohio, and 126 kilometers (78 miles) south of the state capital of Columbus. The plant is located 2 miles east of the Scioto River. The PORTS consists of an 18-square-kilometer (7-square-mile) fenced area with an average elevation of 206 meters (675 feet) above sea level. The area surrounding the plant is primarily forest and farm land. The survey mapped the gamma ray environment of a 78-square-kilometer (30-square-mile) area surrounding the plant.

\subsection{NATURAL BACKGROUND RADIATION}

Natural background radiation originates mainly from three components: (1) terrestrial or radioactive elements present in the earth and earth structure, (2) airborne radon, and (3) cosmic rays emanating from outer space. The terrestrial radiation levels depend upon the type of soil and bedrock immediately below and surrounding the point of measurement. Within building areas, the radiation levels depend on the nature of the building materials.

Radon, a radioactive noble gas, is a by-product of both the uranium and thorium decay chains. It can diffuse through the soil and travel through air. The concentration of radon and its decay products at any location depends on three different factors: (1) meteorological conditions, (2) mineral content of the soil, and (3) soil permeability. Generally, airborne radon contributes from $1 \%$ to $10 \%$ of the natural background levels.

Cosmic rays, high energy radiation originating from outer space, also contribute to the natural radiation background. Radiation levels due to cosmic rays vary with altitude and geomagnetic latitude. Generally, the radiation level ranges from 3.3 microroentgens per hour $(\mu \mathrm{R} / \mathrm{h})$ at sea level to $12 \mu \mathrm{R} / \mathrm{h}$ at an altitude of 3,000 meters $\left(10,000\right.$ feet). ${ }^{1}$ For the PORTS area, the cosmic ray contribution is estimated to be $3.8 \mu \mathrm{R} / \mathrm{h}$.

The primary components of natural terrestrial radiation are potassium- $40\left({ }^{40} \mathrm{~K}\right)$ and the members of the uranium and thorium decay chains. Trace quantities of cesium-137 ( $\left.{ }^{137} \mathrm{Cs}\right)$, a radioactive by-product of nuclear fission, are also present worldwide due to fallout from aboveground testing of nuclear weapons. Site concentrations of these radioactive nuclides produce radiation levels typically ranging from 1 to 15 $\mu \mathrm{R} / \mathrm{h}$ (9 to $130 \mathrm{mrem} / \mathrm{yr}$ ). ${ }^{2}$ These exposure rates vary from one area to another due to the difference in concentration of the previously mentioned radioactive nuclides.

\subsection{SURVEY PROCEDURE}

The 78-square-kilometer (30-square-mile) survey area covered the entire PORTS and its vicinity. The boundary was selected to match the boundary of a similar survey conducted in $1990 .^{3}$ However, the boundary was extended in the northwest to include a part of the Scioto River. The area was surveyed by 
flying a series of parallel east-west flight lines at a nominal altitude of 46 meters ( 150 feet) above ground level (AGL), with a line spacing of 76 meters (250 feet). Lines were flown at a constant ground speed of 36 meters per second ( 70 knots). The lower altitude of the present survey gives a two-fold increase in spatial resolution over the 1984 and 1990 surveys which were flown at 91 meters.

\subsection{SURVEY EQUIPMENT}

The survey was conducted using the MesserschmittBolkow-Blohm (MBB) BO-105 helicopter shown in Figure 1. The helicopter was equipped with two large detector pods and a Radiation and Environmental Data Acquisition and Recorder System, Version IV (REDAR IV).

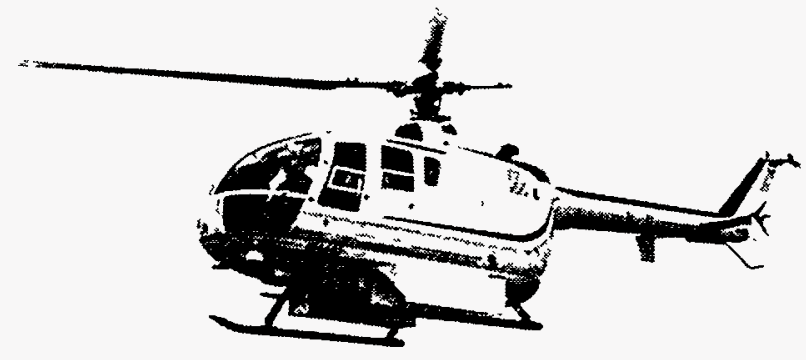

FIGURE 1. MBB B0-105 HELICOPTER WITH DETECTOR PODS

The two large detector pods were mounted on the outside of the skid racks of the helicopter. Each pod contained four 2- $\times 4-\times 16$-inch and one $2-\times 4-\times$ 4-inch sodium iodide, $\mathrm{Nal}(\mathrm{TI})$, gamma ray detectors. At a survey altitude of 46 meters (150 feet) AGL, the eight-detector array and its analog-to-digital convertor (ADC) will exhibit spectral degradation if the ground level exposure rate over a large area exceeds $50 \mu \mathrm{R} / \mathrm{h}$. A single $2-\times 4-\times 16$-inch detector and its $A D C$ extend the dynamic range of the aerial measuring system to about $400 \mu \mathrm{R} / \mathrm{h}$. Above these levels, the pulse rate at the $A D C$ is too high to correctly determine the energy of the gamma rays.

\subsection{REDAR IV System}

Data acquisition was performed using the REDAR IV system, a multi-microprocessor, portable data acquisition and real-time analysis system, designed for use in aircraft. The REDAR IV records the data from the detector system, the aircraft altimeter and positioning systems, and environmental variables such as ambient temperature and barometric pressure. The information is stored on magnetic tape. The REDAR IV is also equipped with multichannel analyzer and CRT display capabilities for in-flight monitoring of the gamma energy spectrum as well as the other flight parameters. The detector and electronic system are described in detail in a separate publication. ${ }^{4}$

\subsection{Helicopter Positioning Method}

The helicopter position was established using the Real-time Differential Global Positioning System (RDGPS) and a radar altimeter. The RDGPS is a navigation system providing continuous position information accurate to \pm 5 meters using a constellation of 24 satellites. The radar altimeter determines the helicopter's altitude by measuring the round-trip propagation time of a signal reflected off the ground.

\subsection{Data Processing Equipment}

The Radiation and Environmental Data Analysis Computer (REDAC) system, housed inside the RSL mobile data processing laboratory located at the Portsmouth Regional Airport (Portsmouth, Ohio), was used to process the aerial data during the survey. The REDAC system hosts a wide range of computer hardware which includes: (1) a computer with 4 megabytes of memory for data manipulation, (2) 2 gigabytes of hard disk space for mass storage of data, (3) $8 \mathrm{~mm}$ tape drives for data transfer and archiving, (4) a 36-inch-wide plotter for data contouring, and (5) two video graphics display stations. The system uses an extensive library of software which provides onsite preliminary analysis of the aerial data on a flight-byflight basis and monitors pre- and post-flight quality assurance checks. A similar REDAC system was used at the RSL Washington, D.C., facility to complete the data analysis.

\subsection{DATA ANALYSIS}

\subsection{Gross Count Procedure}

The gross count (GC) method is based on the integral counting rate in that portion of the spectrum between 
38 and $3,026 \mathrm{keV}$. This count rate, measured in counts per second (cps) at survey altitude, is converted to exposure rate (ER) in $\mu \mathrm{R} / \mathrm{h}$ at 1 meter $A G L$ by using the following algorithm:

$$
E R(\mu R / h)=\frac{(G C-B)}{917} e^{(A-46) C}
$$

where

$$
\begin{aligned}
G C= & \begin{array}{l}
\text { gross count rate at survey altitude } \\
(\mathrm{cps})
\end{array} \\
B= & \begin{array}{l}
\text { background count rate at survey } \\
\text { altitude }(\mathrm{cps})
\end{array} \\
A= & \text { survey altitude }(\mathrm{m}) \\
C= & \text { air attenuation coefficient }\left(\mathrm{m}^{-1}\right)
\end{aligned}
$$

The background count rate, determined on a flight-byflight basis, is comprised of cosmic rays, the aircraft system, and airborne radon. The air attenuation coefficient, $C$, deduced empirically from the altitude profile data at the survey site, was $0.0066 / \mathrm{m}$. The conversion factor $(917$ counts/second $/ \mu R / h)$ for 46 meters (150 feet) AGL was obtained from the documented EG\&G/EM calibration range near Washington, D.C. ${ }^{5}$ The applicability of the conversion factor assumes a uniformly distributed radiation source which covers an area that is large compared to the field of view of the detector system (a circle with a diameter roughly twice the altitude of the aircraft) and has a gamma ray energy distribution similar to that of the natural background of the calibration range.

\subsection{Man-Made Gross Count Extraction Procedure}

The aerial data were also used to determine the location of man-made radionuclides. The man-made gross count (MMGC) is the fraction of the gross counts which is directly attributed to gamma rays from man-made radionuclides. In general, evidence of man-made radionuclides can be found from increases in the gross count rate. However, slight variations in the gross count rate are generally not considered adequate reason to suspect the presence of man-made radionuclides since these variations can result from geological fluctuations or changes in the ground coverage (i.e., river, dense vegetation). Moreover, the aerial data are limited by the minimum detectable activity of the AMS, which varies with the survey altitude and the radionuclide. The calculated minimum detectable activities of uniform soil concentrations of uranium-235 (235U) and protactinium-234m (234mPa) at 46 meters and an aircraft speed of 36 meters/ second are 1.8 and $0.44 \mathrm{pCi} / \mathrm{g}$, respectively.

The MMGC rate can be expressed analytically in terms of the integrated count rates in specific spectral energy windows (in keV) from the gamma energy spectrum

$$
\begin{aligned}
M M G C & =\sum_{E=38 \mathrm{keV}}^{1394 \mathrm{keV}} \text { Counts }_{E} \\
& -K \cdot \sum_{E=1394 \mathrm{keV}}^{3026 \mathrm{keV}} \text { Counts }_{E}
\end{aligned}
$$

$K$ is defined over a survey area that only contains gamma radiation from naturally-occurring radionuclides as

$$
K=\sum_{E=38 \mathrm{keV}}^{1394 \mathrm{keV}} \text { Counts }_{E} / \sum_{E=1394 \mathrm{keV}}^{3026 \mathrm{keV}} \text { Counts }_{E}
$$

Large changes in gross counting rates from natural radiation usually produce only small changes in spectral shape because the natural gamma emitters change in a relatively constant ratio as the detector moves from one location to another. The MMGC algorithm is proportional to the deviation of an energy spectrum from a natural background spectral shape. Although this procedure can be applied to any region of the gamma spectrum, the most common practice is to place all counts below $1,394 \mathrm{keV}$ into the manmade window and to place all counts above $1,394 \mathrm{keV}$ into the natural window. Therefore, the low energy or man-made window contains the region of the gamma energy spectrum where most long-lived, man-made radionuclides emit radiation, and the high energy or natural window contains the region of the gamma energy spectrum where mostly naturally-occurring radionuclides emit radiation. This MMGC algorithm has been found to be sensitive to low levels of manmade radiation (i.e., $<1 \mu \mathrm{R} / \mathrm{h}$ ) even in the presence of large variations in the natural background. 
Since the MMGC algorithm responds to a wide range of radionuclides, the primary function of the MMGC is to locate man-made radioactivity. Once a region of man-made radioactivity has been identified, a detailed analysis of the gamma energy spectrum is conducted to ascertain the radionuclides present.

\subsection{GROUND-BASED MEASUREMENT PROCEDURE}

During the PORTS survey, soil samples and exposure rates were measured at four locations outside the plant boundary. These measurements were used to support the integrity of the aerial data. These locations were not near any obvious radiation anomalies. A Reuter-Stokes pressurized ionization chamber was used for each exposure rate measurement at a height of 1 meter AGL at the center of a measurement area 18 meters (60 feet) in diameter. Soil samples to a depth of 15 centimeters ( 6 inches) were also obtained at four points inside each circular measurement area. The soil samples were dried, and their gamma ray activities were measured using a high purity germanium detector system located at EG\&G/EM's Santa Barbara Operations office. Detailed descriptions of the procedure used for soil sample data collection and analysis are outlined in separate publications. 6,7

\subsection{DISCUSSION OF RESULTS}

\subsection{Terrestrial Gamma Exposure Rate Contour Map}

Figure 2 shows the gamma ray energy spectrum extracted from the aerial data outside the boundaries of the plant. This spectrum is typical of the area's natural background and results primarily from contributions by radionuclides in the uranium and thorium decay chains and ${ }^{40} \mathrm{~K}$.

The terrestrial exposure rates deduced from the aerial data were integrated with their corresponding aircraft position coordinates to produce a contour map. Figure 3 shows the terrestrial exposure rate contour map superimposed on the 1990 aerial photograph of PORTS, showing the exposure rates in $\mu R / h$ at 1 meter AGL inferred from the aerial data.

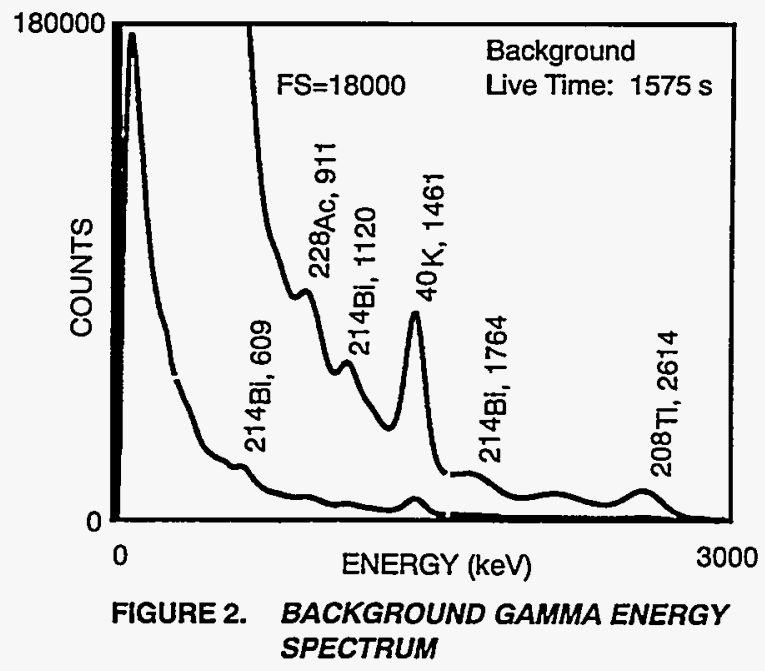

The terrestrial background exposure rates ranged from approximately 7 to $14 \mu \mathrm{R} / \mathrm{h}$ over most of the survey area. A cosmic ray exposure rate of $3.8 \mu \mathrm{R} / \mathrm{h}$ is included in the radiation data.

The exposure rates shown in Figure 3 agree well with the rates from the 1984 survey. ${ }^{8}$ Even though the $\mu \mathrm{R} / \mathrm{h}$-at-1-meter values of the contour levels are very different, the shapes of the radiation contours are approximately the same and the values at a specific location agree to within the resolution of the contours.

The 1990 survey was conducted at an altitude of 91 meters ( 300 feet). ${ }^{3}$ The terrestial exposure rate plot is the only data shown and the regions of interest (ROIs) are identified on that plot. The 1990 regions marked AR-1 and AR-5 agree in shape and intensity with the same areas in the 1993 survey (ROI 1 and ROI 2). AR-2 is the location of the truck carrying a cask of processed material and is not present in either the 1984 or 1993 survey data. AR- 6 identifies the processing plant, but no specific exposure rate level is associated with this location in the 1990 data. The contour level $(7-9 \mu \mathrm{R} / \mathrm{h})$ is the same as that in the 1984 data and is consistent with the $0-8 \mu \mathrm{R} / \mathrm{h}$ level in the 1993 data.

The two remaining areas identified in the 1990 survey (AR-3 and AR-4) are a little more difficult to explain. This area of the plot is similar to the contour levels shown in the 1984 plot, but AR-4 is much stronger in 1990 than it was in 1984. In the 1993 survey, these two areas appear as a single kidney bean-shaped region whose two lobes are spaced slightly closer together than the peaks in the 1984 and 1990 surveys. It is difficult to determine exactly what the cause of this shape change might be. It may be the result of a different distribution of the ${ }^{238} \mathrm{U}$ storage in the feed cylinders, or 


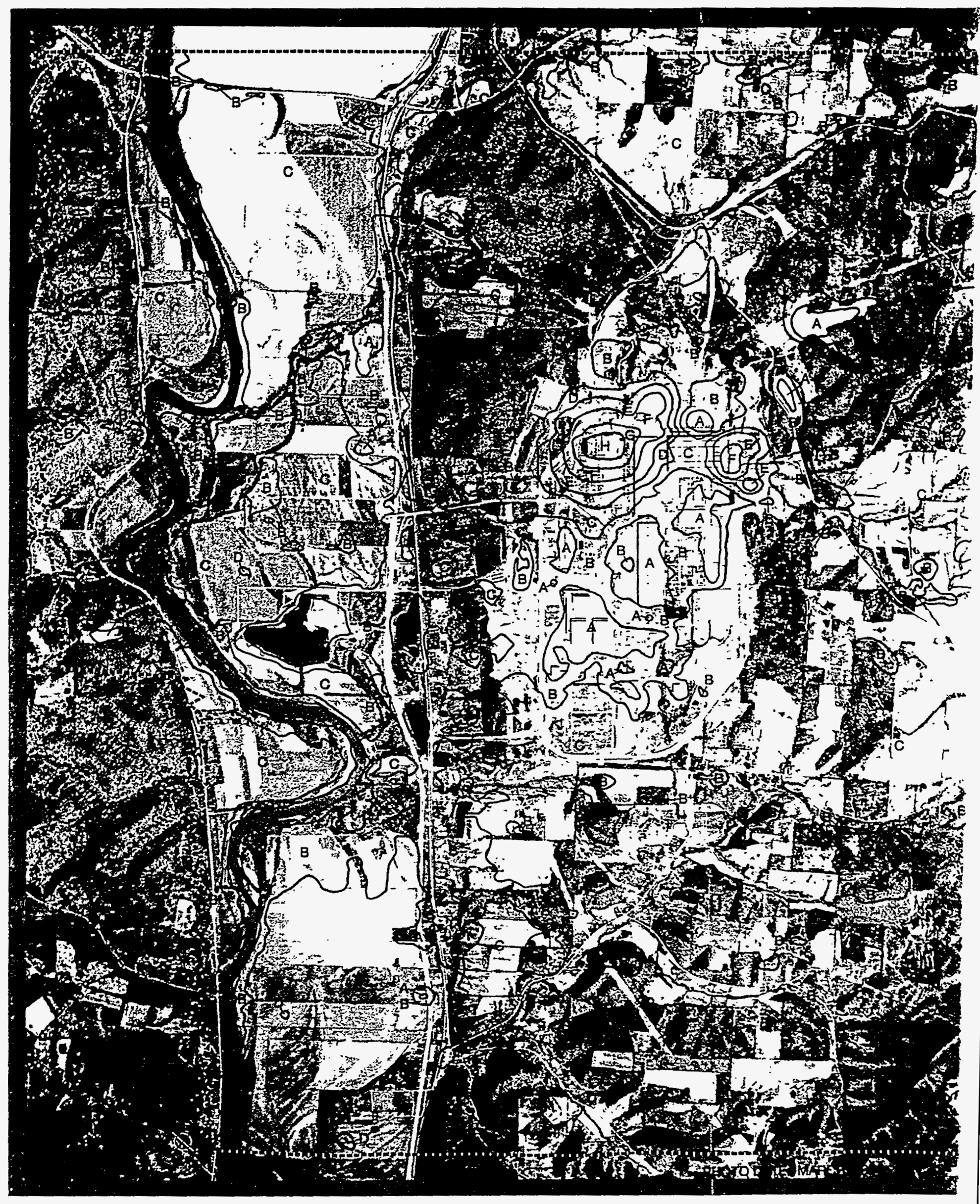

FIGURE 3. TERRESTRIAL GAMMA RADIATION EXPOSURE RATE CONTOUR MAP 
(1) 3.

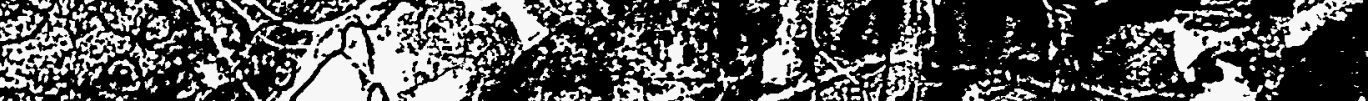

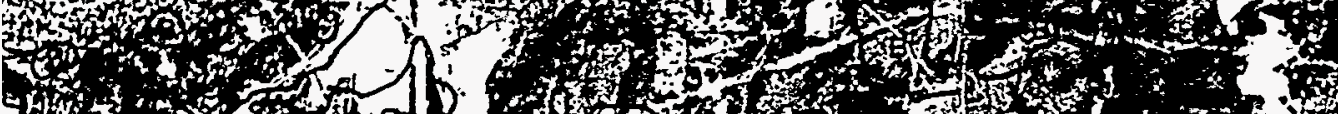
(4)

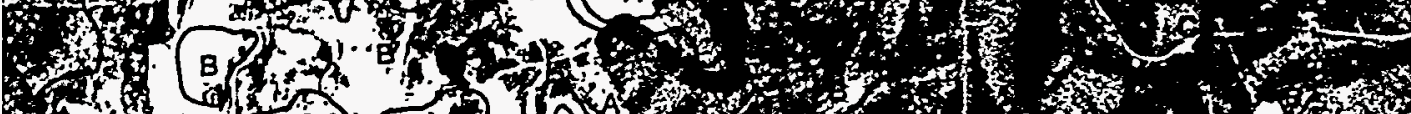
(1)

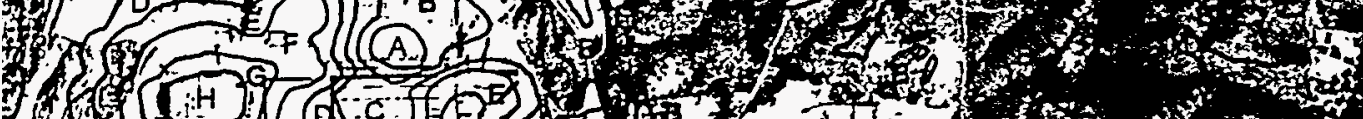
BE 4 ( (2) 170 act

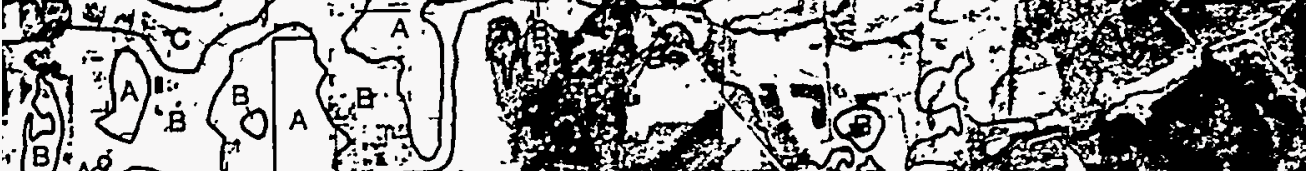
: S ton 我 Th a

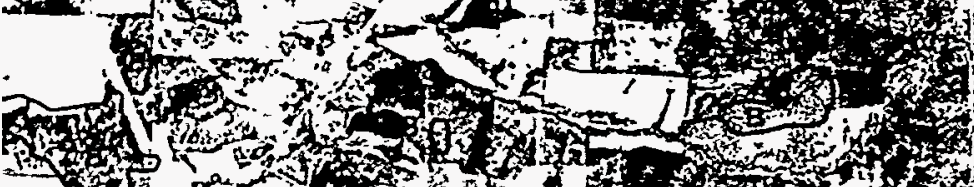
1 ,

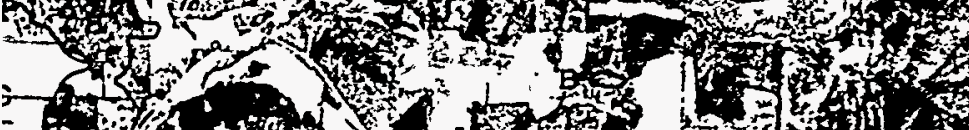
in - G6. if

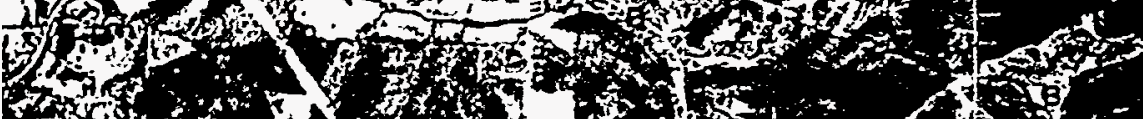
5 A

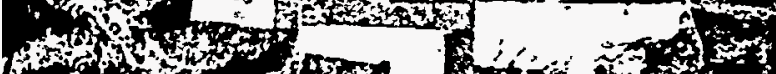
H.
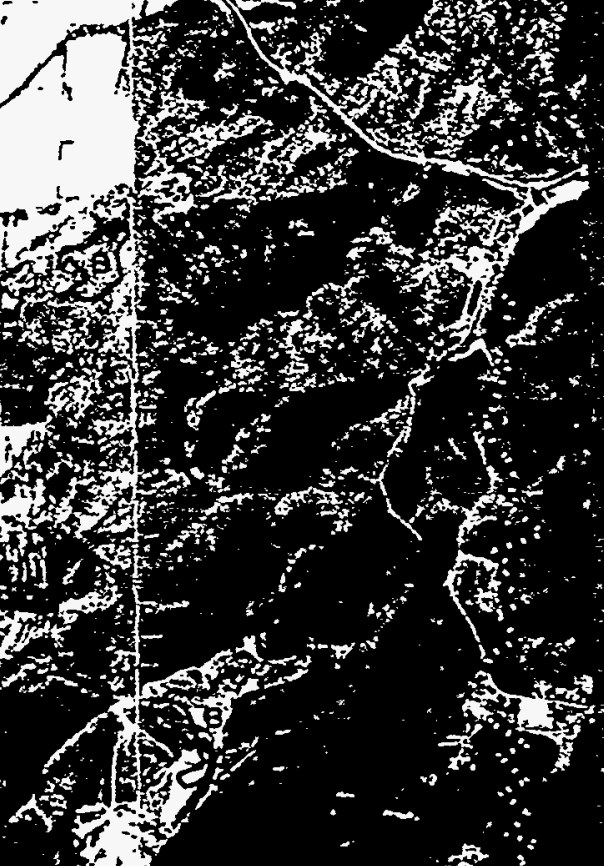
H

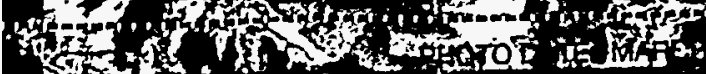
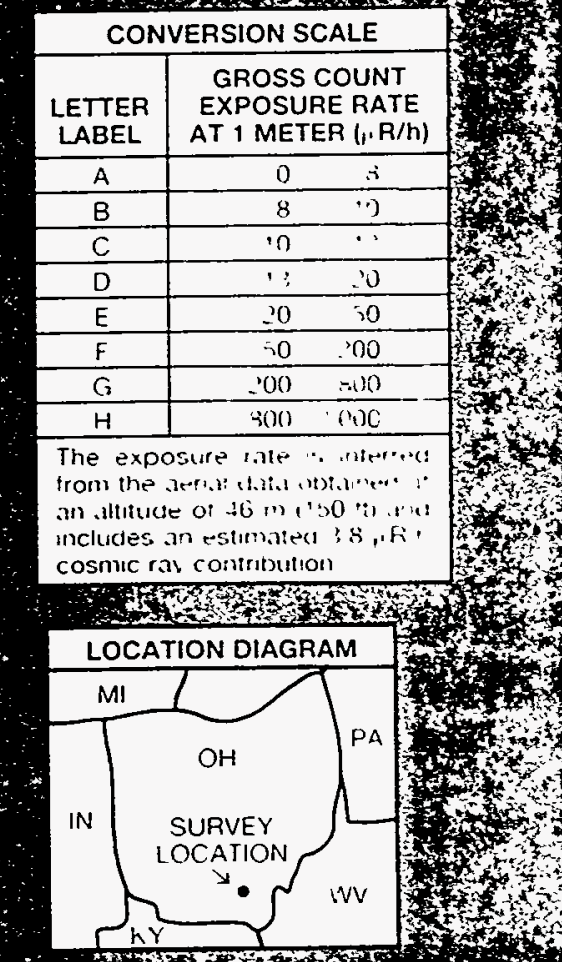
$-x^{2}$

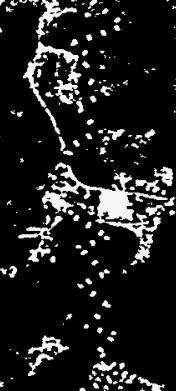
1) $\frac{1}{2}$

ixt

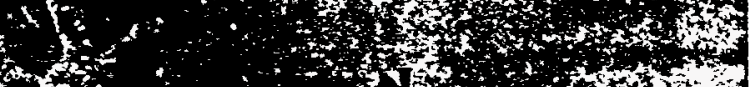
it $+3$ th

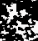


the different helicopter altitudes may see the source material through different amounts of shielding. The 1984 sunvey was performed at 76 meters ( 250 feet), the 1990 survey was performed at 91 meters (300 feet), and the 1993 survey was performed at 46 meters (150 feet).

An earlier survey of the plant was performed in $1976 .^{9}$ The exposure rate and man-made radiation contours are so different from those in the 1984,1990 , or 1993 surveys that a major change must have occurred in the location of the processing and storage of material at the site. No comparison will be made with the 1976 data.

\subsection{Man-Made Gross Count Contour Analysis}

The MMGC algorithm (discussed in Section 6.2) was used to study the aerial data for man-made gamma emitters in the survey area. Figure 4 shows seven ROls with detectable levels of man-made radionuclides.

Figure 5 shows the gamma energy spectra extracted from the seven sites. The analysis of the gamma energy spectra extracted from six sites shows the presence of $234 \mathrm{mPa}$, which is a decay product of uranium-238 ( $\left.{ }^{238} \mathrm{U}\right)$, and only ROI 5 shows detectable quantities of $235 \mathrm{U}$.

The contour levels shown in Figure 4 outline the same general features seen in the 1984 man-made contour map. Comparisons of the intensities of the ROls cannot be made in any quantitative manner. The two surveys were flown at significantly different altitudes (1984 at 76 meters and 1993 at 46 meters). A point source should appear with almost three times as many counts/second at 46 meters than at 76 meters. If the same amount of material was present during both surveys, the 1993 survey should display three times as many counts over the point as the 1984 survey.

ROIs 1, 2, and 3 are present in both surveys, although ROI 3 has a northerly extension in the 1984 survey and is significantly weaker in 1993. ROIs 4 and 5 appear to be new features in the 1993 data. If the material at ROI 4 was present during the 1984 survey, it likely would not have been seen since its signal would have been overwhelmed by the signal from $\mathrm{ROI}$ 3. ROI 5 is too weak to be seen in the 1984 data; ROI 3 's area is heavily influenced by the edge of the strong bulls-eye pattern of the 1984 data at ROI 3. ROls 6 and 7 match similar small, low-intensity areas seen in the 1984 data.

No plot of the man-made data is presented for the 1990 survey. The exposure rate regions for ROls 1-4 were discussed above in Section 8.1. ROls 5-7 are weak enough that they would not be expected to show in the exposure rate plot, and they were compared to the 1984 data above.

\subsection{Ground-Based Measurements}

Soil samples and in situ pressurized ion chamber measurements were collected at four sites within the survey boundaries during the aerial survey. These same sites were used in the 1984 and 1990 surveys. ${ }^{3,8}$ The exposure rates were computed from the primary isotopic concentrations in the soil samples and included the effect of soil moisture (see Table 1). The calculated soil exposure rate values are compared with the ion chamber measurements and the aerial measurements in Table 2. The exposure rates inferred from the aerial survey data were found to be in excellent agreement $( \pm 7.5 \%)$ with the groundbased measurements.

Small differences in the exposure rates from the comparative methods are due to the following:

1. The aerial data were not taken at exactly the same places and times as the ground data.

2. Each 1-second data point obtained with the airborne system covers an area several thousand times as large as that of a measurement made at a 1-meter height (such as with an ion chamber), and an area several million times as large as that of a typical soil sample.

3. Since only a limited number of soil samples were taken, statistical deviations are significant.

\subsection{SUMMARY}

A radiological survey of the PORTS and surrounding area was conducted August 10-16, 1993. The aerial survey was flown at an altitude of 46 meters (150 feet) using the AMS. Seven areas of elevated exposure rates were detected within the boundaries of the plant. ROIs $1-4$ and 6-7 contained $234 \mathrm{mPa}$, a decay product of ${ }^{238} \mathrm{U}$. Only one area (ROI 5) showed detectable quantities of ${ }^{235} \mathrm{U}$. Table 3 correlates the seven sites with locations (buildings) inside the plant. 




FIGURE 4. MAN-MADE GAMMA RADIATION CONTOUR MAP 

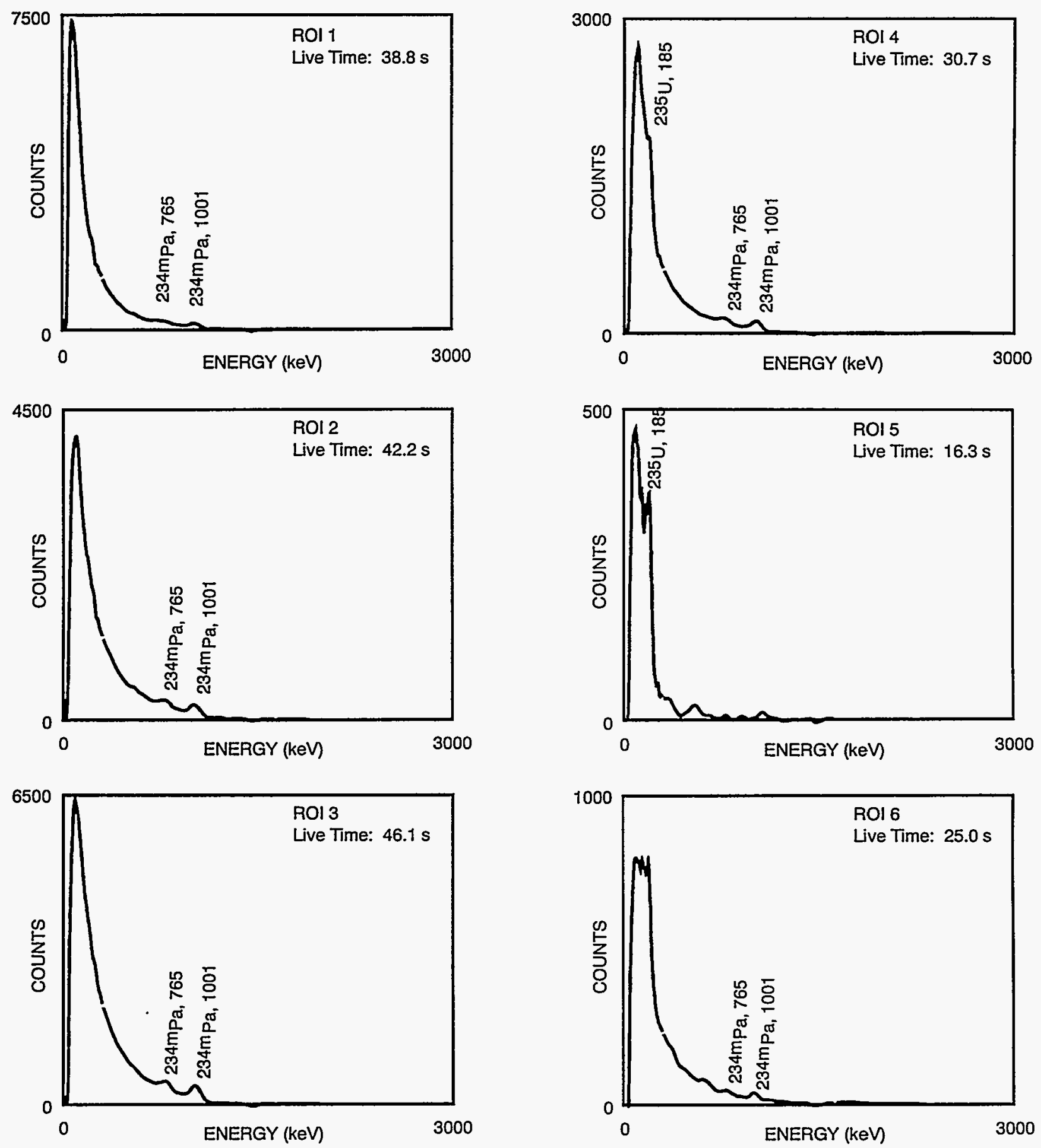

FIGURE 5. GAMMA ENERGY SPECTRA OF THE SEVEN SITE LOCATIONS 


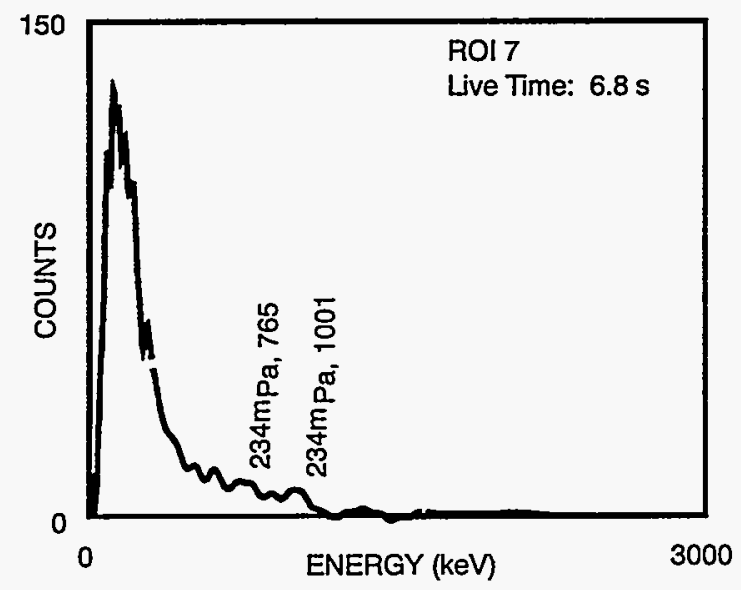

FGURE 5. GAMMA ENERGY SPECTRA OF THE SEVEN SITE LOCATIONS (Continued)

\begin{tabular}{|c|c|c|c|c|c|c|}
\hline Site ${ }^{a}$ & Date & $\begin{array}{c}\text { Soil } \\
\text { Moisture } \\
\text { (\%) }\end{array}$ & $\begin{array}{l}{ }^{238} \mathrm{U} \\
\text { (ppm) }\end{array}$ & $\begin{array}{l}{ }^{232} \mathrm{Th} \\
\text { (ppm) }\end{array}$ & $\begin{array}{c}{ }^{137} \mathrm{Cs} \\
(\mathrm{pCi} / \mathrm{g})\end{array}$ & $\begin{array}{c}40 \mathrm{~K} \\
(\mathrm{pCi} / \mathrm{g})\end{array}$ \\
\hline \multirow[t]{3}{*}{1} & 1993 & $13 \pm 4$ & $3.3 \pm 0.9$ & $9.2 \pm 3.7$ & $0.23 \pm 0.20$ & $13 \pm 4$ \\
\hline & 1990 & $19 \pm 4$ & $3.7 \pm 1.0$ & $10.9 \pm 2.1$ & $0.21 \pm 0.02$ & $15 \pm 3$ \\
\hline & 1984 & $21 \pm 4$ & $2.4 \pm 0.7$ & $8.2 \pm 3.5$ & $0.28 \pm 0.16$ & $12 \pm 4$ \\
\hline \multirow[t]{3}{*}{2} & 1993 & $17 \pm 1$ & $4.2 \pm 0.6$ & $11.9 \pm 1.8$ & $0.23 \pm 0.06$ & $12.3 \pm 0.8$ \\
\hline & 1990 & $21 \pm 1$ & $3.6 \pm 0.4$ & $9.9 \pm 0.4$ & $0.63 \pm 0.07$ & $11 \pm 2$ \\
\hline & 1984 & $26 \pm 5$ & $3.0 \pm 0.9$ & $10.1 \pm 0.9$ & $0.48 \pm 0.04$ & $12 \pm 2$ \\
\hline \multirow[t]{3}{*}{3} & 1993 & $13 \pm 3$ & $3.6 \pm 0.6$ & $9.2 \pm 1.8$ & $0.17 \pm 0.08$ & $12 \pm 2$ \\
\hline & 1990 & $16 \pm 1$ & $4.0 \pm 0.2$ & $7.7 \pm 0.3$ & $0.24 \pm 0.02$ & $13.9 \pm 0.5$ \\
\hline & 1984 & $16 \pm 1$ & $3.1 \pm 0.3$ & $7.5 \pm 0.6$ & $0.20 \pm 0.06$ & $13.8 \pm 0.8$ \\
\hline \multirow[t]{3}{*}{4} & 1993 & $15 \pm 2$ & $3.9 \pm 0.3$ & $9.8 \pm 0.5$ & $0.24 \pm 0.03$ & $10.1 \pm 0.5$ \\
\hline & 1990 & $21 \pm 1$ & $3.8 \pm 0.4$ & $8.9 \pm 0.3$ & $0.23 \pm 0.11$ & $9.3 \pm 0.6$ \\
\hline & 1984 & $25 \pm 2$ & $2.8 \pm 0.2$ & $9.7 \pm 0.6$ & $0.36 \pm 0.33$ & $9.0 \pm 0.3$ \\
\hline
\end{tabular}

a Site Locations: 1. Lat: N $39^{\circ} 02^{\prime 2} 24.5^{\prime \prime}$ and Lon: W $82^{\circ} 57^{\prime} 53.6^{\prime \prime}$

2. Lat: $N 38^{\circ} 59^{\prime} 34.8^{\prime \prime}$ and Lon: $W 82^{\circ} 58^{\prime} 35.1^{\prime \prime}$

3. Lat: $N 39^{\circ} 01^{\prime} 20.3^{\prime \prime}$ and Lon: $W 8^{\circ} 01^{\prime} 50.8^{\prime \prime}$

4. Lat: N 39 $00^{\prime} 29.8^{\prime \prime}$ and Lon: W 82 ${ }^{\circ} 58^{\prime} 08.4^{\prime \prime}$ 


\begin{tabular}{|c|c|c|c|c|}
\hline \multirow[b]{2}{*}{ Site ${ }^{a}$} & \multirow[b]{2}{*}{ Date } & \multicolumn{3}{|c|}{$\begin{array}{c}\text { Exposure Rate } \\
(\mu \mathrm{R} / \mathrm{h} \text { at } 1 \text { Meter AGL) }\end{array}$} \\
\hline & & $\begin{array}{c}\text { Soil } \\
\text { Analysis }^{b}\end{array}$ & $\begin{array}{c}\text { lon } \\
\text { Chamber }\end{array}$ & $\begin{array}{c}\text { Inferred Aerial } \\
\text { Datab }\end{array}$ \\
\hline \multirow[t]{3}{*}{1} & 1993 & $10.0 \pm 2.0$ & $11.0 \pm 0.6$ & $10.9 \pm 0.5$ \\
\hline & 1990 & $10.7 \pm 1.2$ & $10.3 \pm 0.5$ & $10.0 \pm 1.0$ \\
\hline & 1984 & $9.0 \pm 1.3$ & $10.2 \pm 0.5$ & $11.5 \pm 2.5$ \\
\hline \multirow[t]{3}{*}{2} & 1993 & $10.9 \pm 0.8$ & $10.9 \pm 0.8$ & $10.1 \pm 0.2$ \\
\hline & 1990 & $9.8 \pm 0.5$ & $9.4 \pm 0.5$ & $10.0 \pm 1.0$ \\
\hline & 1984 & $9.6 \pm 0.7$ & $9.6 \pm 0.5$ & $11.5 \pm 2.5$ \\
\hline \multirow[t]{3}{*}{3} & 1993 & $10.0 \pm 1.0$ & $10.0 \pm 1.0$ & $9.7 \pm 0.4$ \\
\hline & 1990 & $10.0 \pm 0.3$ & $9.6 \pm 0.5$ & $10.0 \pm 1.0$ \\
\hline & 1984 & $9.6 \pm 0.5$ & $10.1 \pm 0.5$ & $11.5 \pm 2.5$ \\
\hline \multirow[t]{3}{*}{4} & 1993 & $10.0 \pm 0.6$ & $10.0 \pm 0.6$ & $9.7 \pm 0.2$ \\
\hline & 1990 & $9.3 \pm 0.5$ & $9.7 \pm 0.5$ & $10.0 \pm 1.0$ \\
\hline & 1984 & $9.0 \pm 0.3$ & $9.6 \pm 0.5$ & $10.0 \pm 1.0$ \\
\hline
\end{tabular}

ame site locations as Table 1.

b Includes an estimated cosmic ray contribution of $3.8 \mu \mathrm{R} / \mathrm{h}$. Uncertainities presented for the 1993 data are statistical only.

\begin{tabular}{|c|l|l|l|}
\hline \multicolumn{4}{|c|}{ Table 3. Location of Man-Made Detected Sites } \\
\hline ROI & \multicolumn{1}{|c|}{ Location } & \multicolumn{1}{|c|}{ Description } & Isotope \\
\hline 1 & West of Bldg. X-330 & Cylinder Yard & $234 \mathrm{mPa}$ \\
2 & North of Bldg. X-344-A & Cylinder Yard & $234 \mathrm{mPa}$ \\
3 & South of Bldg. X-343 & Cylinder Yard & $234 \mathrm{mPa}$ \\
4 & Bldg. X-744-G & Building & $234 \mathrm{mPa}$ \\
5 & Northeast of Bldg. X-705 & Cylinder Yard & $235 \mathrm{U}$ \\
$6 \& 7$ & Northeast of Bldg. X-326 & Conveyer and Loading & $234 \mathrm{mPa}$ \\
& & Dock Area & \\
\hline
\end{tabular}




\section{APPENDIX A \\ SURVEY PARAMETERS}

Survey Site:

Survey Coverage:

Survey Date:

Survey Altitude:

Aircraft Speed:

Line Spacing:

Navigation System:

Line Direction:

Detector Configuration:

Acquisition System:

Conversion Factor:

Air Attenuation Coefficient:

Aircraft:

Project Scientist:
Portsmouth Gaseous Diffusion Plant Piketon, Ohio

$78 \mathrm{~km}^{2}\left(30 \mathrm{mi}^{2}\right)$

August 10-16, 1993

$46 \mathrm{~m}(150 \mathrm{ft})$

$36 \mathrm{~m} / \mathrm{s}$ (70 knots)

$76 \mathrm{~m}(250 \mathrm{ft})$

GPS Differential System

East-West

Eight 2- $\times 4-\times 16$-in $\mathrm{Nal}(\mathrm{Tl})$ detectors Two 2- $\times 4-\times 4$-in $\mathrm{Nal}(\mathrm{Tl})$ detectors

REDAR IV

$917 \mathrm{cps} / \mu \mathrm{R} / \mathrm{h}$

$0.0066 / \mathrm{m}$

MBB BO-105 Helicopter

G. Sampoll-Ramirez 


\section{REFERENCES}

1. Klement, A. W., et. al. Estimates of Ionizing Radiation Doses in the United States 1960-2000, U. S. EPA Report ORP/CSD72-1. EPA, Washington, D. C., 1972.

2. Lindeken, C. L., et. al. "Geographical Variations in Environmental Radiation Background in the United States," Proceedings of the Second International Symposium on the Natural Radiation Environment, August 7-11, 1972, Houston, Texas: Vol. 1. National Technical Information Service, U. S. Department of Commerce, Springfield, Virginia, 1972, pp 317-332.

3. Guss, P. P. An Aerial Radiological Survey of the Portsmouth Gaseous Diffusion Plant and Surrounding Area, Date of Survey: July 1990, Report No. EGG-10617-1154. EG\&G/EM, Las Vegas, NV, 1992.

4. Boyns, P. K. The Aerial Radiological Measuring System (ARMS): Systems; Procedures and Sensitivity, Report No. EGG-1183-1691. EG\&G/EM, Las Vegas, Nevada, 1976.

5. Mohr, R. A. Ground Truth Measurements at the Calvert County, Maryland Test Line, Report No. EGG-10282-2066. EG\&G/EM, Santa Barbara, California, 1985.

6. Quam, W. and K. Engberg. Low Background Ge(Li) Detector with Anticoincidence NaI Annulus (2nd Revision), Report No. EGG-1183-2326 (Rev.). EG\&G/EM, Santa Barbara, California, 1978.

7. Mohr, R. A., A. E. Fritzsche, and L.A. Franks. Ground Survey Procedures, Report No. EGG-1183-2339. EG\&G/EM, Santa Barbara, California, 1976.

8. Colton, D. P. An Aerial Radiological Survey of the Portsmouth Uranium Enrichment Plant, Date of Survey: May 1984, Report No. EGG-10282-1081. EG\&G/EM, Las Vegas, Nevada, 1985.

9. Feimster, E.L. An Aerial Radiological Survey of the Area Surrounding the Portsmouth Gaseous Diffusion Plant, Date of Survey: July 1976, Report No. EGG-1183-1719. EG\&G/EM, Las Vegas, Nevada, 1979. 


\section{DISTRIBUTION}

\section{DOE/DP}

L.E. Gordon-Hagerty

O.W. Taylor

(1)

(1)

\section{DOE/HQ}

OSTI

(25)

DOE/NSIC

R.S. Scott

DOE/NV

M.R. Dockter

C.A. Santilli

(1)

(1)

\section{DOE/OR}

R. Sleeman

(20)

\section{DOE/PORTSMOUTH}

G. Gillespie

(5)

\section{EG\&G/EM}

J.F. Doyle

LVAO

G.R. Shipman

WAMO

W. J. Tipton

LVAO

G. Sampoll-Ramirez WAMO

P.H. Zavattaro

LVAO

(1)

(1)

(1)

(1)

(1)

\section{LIBRARIES}

RSL

TIC

(30)
(1)

(1)

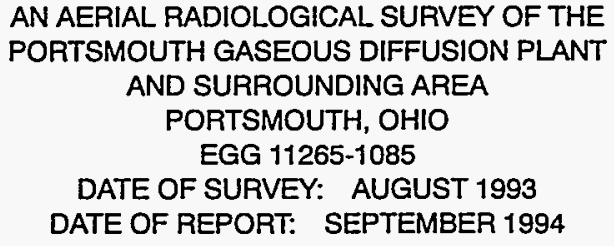

